\title{
Market Orientation, Firms' Level Characteristics and Environmental Factors: Investigating the Moderating Effects on E-Commerce Competence.
}

\author{
Dr. Amue, Gonewe J. ${ }^{1}$ Dr. Igwe R. Sunny ${ }^{2}$ \\ ${ }^{1}$ Senior lecturer, department of marketing, university of port Harcourt, nigeria \\ ${ }^{2}$ Lecturer department of marketing, university of port Harcourt, nigeria
}

\begin{abstract}
The study assesses the effect of firms' level characteristics, market orientation and environmental factors on the influence of e-commerce competence development on organizations' performance. Data were drawn from 130 managers from a population of 193 managers of all the airline firms in the industry. Partial correlation coefficient was used to test the moderating effect of variables of study. The result shows that firms' level characteristics and proactive market orientation moderate the influence of e-commerce competence development on organizational performance. Based on these findings, we conclude that certain market culture and firms' level characteristics affect the influence of e-commerce competence on performance. We therefore recommend that e-commerce firms should anticipate latent needs by offering technological advances that enables them to lead customers to new and better value proposition and satisfaction.
\end{abstract}

Keyword: Firms' Level Characteristics, Market Orientation, Environmental Factor, E-Commerce Competence, Organizations' Performance.

\section{Introduction}

The link between electronic commerce and firm performance has accelerated research concern in electronic commerce capability building and development, and in particular, the concept of e-marketing has attracted a huge research interest over a decade. A number of researchers in marketing domain has argued the possibility that e-commerce competence building and development contributes to organizational performance through the capabilities it helps to develop in the firm (Morgan and Sanchez, 2008; Timil and Bartus, 2006). In fact, ensuring firm success can be considered the ultimate goal of capability development efforts in organization (Clarkson and Batubo, 2010). Much work on the link between e-commerce capability development and firm performance are far from being fully explained. The relationship between the three components of (Amit's and Jean's, 2005) conceptualization of e-commerce capability and firm performance, in particular, meets very mixed findings and arguments in the literature (e.g. Assenkasan and Bolton, 2009; Ziklag and Firstman, 2008 and Hall, 2010). Consequently, Tarus and Kalu (2012), have recently argued that the focal issue of whether ecommerce capability accelerate or retards performance in organization remains area of research. These differences in the findings of researchers have led to more studies into exploring how other contextual variables could possibly influence the effects of e-commerce competence on organizations' performance.

Thus, the purpose of this paper is to examine how e-commerce competence development in organization interacts with other variables to influence firm performance. Our research works differ from previous studies on e-commerce capability and performance measures, this is because previous studies looked at the relationships between competence development and performance, but this study examines the influence of e-commerce competence performance thus contributing to existing literature. Again, the e-commerce competence development may be contingent upon other variables, and this is consistent with previous studies (Amit's and Jean's, 2005; Hongwei and Jiang, 2006; Ziklag and Nicher, 2003). Thus, we consider the moderating effects of market orientation, firms level characteristics and environmental factors, on the relationship between ecommerce competence development and organizational performance. Dandison and Mitches (2011) claims that the role of market orientation has been neglected in e-commerce capability studies. But Amit and Jean (2005) posit that market orientation serves as a platform to leverage e-commerce competence development. Furthermore, we investigate how environmental factors moderate the effect of e-commerce capabilities on firm performance. With regard to firm level characteristics, (Hensmans et al, 2001; Park and Campbell, 2001) buttress the role of firm level characteristics on the influence of e-commerce practices in business. Finally, we expect that the moderating effects of market orientation, firms' condition and environmental forces will help explain some of the contradictory findings in the literature. 


\subsection{Conceptual Framework And Hypotheses}

Firm performance and e-commerce competence, market orientation, conditions of the firm and environmental factors play a moderating function. E-commerce competencies are the skills and subroutines that underpin the process of conducting trade over the internet, it enable the firm to execute strategies for the internet (Amit and Zott, 2001). E-commerce processes are closely entangled with capabilities, because it is capabilities that enable the execution of employee knowledge, skills, technical and managerial systems to facilitate internet based commercial activities (Amit and Zott, 2001). Secondly, capabilities are deeply embedded, imitable and immobile; they are specific to a firm and are likely to contribute substantially to competitive advantage (Shelfat and Peteraf, 2003). The inimitability and immobility can tap into them frequently to carry out strategic execution for e-commerce (Day, 1994).

We conceptualize a set of e-commerce capabilities on the basis of our assessment of key processes and skills that a firm needs to conduct commercial transactions over the internet. These capabilities are information technology (IT) capability, strategic flexibility (SF) capability and trust building (TB) capability. IT capability is indispensable to e-commerce because a firm's ability to process information and move it around securely within and outside the firm drives commercial transaction on the internet (Varadarajan and Yadav, 2002). Strategic flexibility plays an important role in e-commerce because the ability to adapt and redeploy resources easily in the face of a constantly changing market place becomes critical. Furthermore, the ability to engender trust on the part of the trading partners for online exchange in real time is particularly critical. However, many people still do not understand very well, the links between the components of e-commerce capability and organization performance. Following previous research (e.g., Amit's and Jean's, 2005; Hongwei and Jiang, 2006; Ziklag and Nicher, 2003), we consider how other organizational factors, namely firms' level characteristics, market orientation and also environmental factors, might interact with e-commerce competencies components to affect organizational performance.

\subsection{Firms' Level Characteristics}

Firms' level characteristics can be seen as an organization's profile in terms of size, age and experiences in business undertaking (Zorlly and petersize 2010). Siclear and tamilus (2007) considered it a measure of organizational factor, our central premise is that strong, reliable and effective e-commerce capability generate positive performance outcome for the firm and that the influence of e-commerce competence may vary according to firm level characteristics (benzack and srivenance, 2008). The relationship between firm level characteristics (firm size, firm age, experience) and its moderating effect of certain e-commerce competencies on performance is independent of firm size, but empirical studies suggest that Gilbert's law does not hold when applied to real data. Singh and Whittington (1975) quoted in piros (2011) argued that firms in manufacturing, construction and distribution sectors performance decreases with size of the firm. Maryland and Martins (2009) posit that firm performance outcome decreases with firm age, and this is consistent with Jovanvic's (1982) theory of firm performance.

According to Jovanovich theory, firms uncover their true efficiencies overtime period with a Bayesian learning process. Evans (1987) cited in Dickson and better (2008) argued that firm performance decreases with size, which is not consistent with Gilbert's law, moreover Evans also concluded that the relationship between firm's performance outcome and firm size is highly-non-linear one. From the review of literature, we have seen that certain firm-level characteristics, such as firm size, age and experience are likely to ameliorate a firm's ability to signal trustworthiness (Amit and Jean, 2005). In the tumultuous world of e-commerce, in which organizational longetivity is rare, age leads to firm's credibility. Unethical firms are unlikely to survive, and firms that have survived must be more worthy of trust by virtue of their continuous survival. Thus, age should serve to buttress and validate a firm's trust-building capability, making its efforts to build trust more credible and effective. The buttressing role of age is particularly important in the financial industry (Hensmans et a, 2001 and Campbell, 2001). In addition to signaling reputation, age also implies that the firm possesses greater knowledge stocks gained from learning and experience. in this context, we propose the following:

H1: the longer a firm level characteristics, the more skilled it is in all aspects of strategy and the more effective it is in leveraging e-commerce competencies.

\subsection{Market Orientation}

Market orientation can be seen as a culture focused on being responsive to customer needs and competitors' activities to create customer value (Narver and Slater, 1990). Jaworski et al (2000) considered market orientation as a measure of organizational factor. This is a facet of organizational culture that reflects the extent, to which the firm is open to new ideas, accepts and stimulates novel approaches to market needs. Market orientation is conceptualized into market-driven and market-driving perspectives (Jaworski et al, 2001). 
According to the market-driven perspective, firms are responsible to the needs and changes of the market place, and thus they exhibit responsive market orientation. In contrast, the market-driving perspective posits that firms act to induce changes in the market and thus exhibit proactive market orientation.

\subsection{Responsive Market Orientation}

Another name for responsive market orientation is customer orientation. It is an orientation where customers is placed at the core of the strategic planning and of being receptive and highly sensitive to understanding and servicing customer needs (Slater and Narver, 1998). A responsive market orientation involves accepting the structures and constraints of the market as they are. The firm culture operates on the premise that customer know and they can articulate their wants and needs. If such expressed wants and needs are understood the firm simply responds appropriately to gain competitive advantage (Day, 1999). A number of authors argue that an over-reliance on customer feedback impacts negatively on the degree of new product development and innovativeness. Christensen and bower (1996) cited in Macuson and Binta (2010) contend that many large organizations fail because "they listen too carefully to their customer and customer place stringent limits on the strategies firms can and cannot pursue." Underlying this claim is the idea that frequently, customers do not know how their needs will evolve and how certain technologies may impact on the satisfaction of their needs (Augusto and Coelho, 2007). Therefore, it is reasoned that market culture, based on customer orientation are forced into developing new products that are similar to existing ones. This can be detrimental to the firm, thus, although responsive marker orientations provide a platform for leveraging certain capabilities, we argue that responsiveness to expressed customer needs is not enough for an e-commerce firm and that it can be as important to focus on anticipating latent customer needs and on shaping and defining how they can be met. We therefore, hypothesized as follows:

$\mathrm{H} 2$ : the higher the responsive market orientation, the greater is the influence of e-commerce competence development on organizational performance.

\subsection{Proactive Market Orientation}

Amit and Jean (2005) posit that successful e-commerce business, such as online stock trading (e-trade), online auctions (ebay), interactive customer health care information are as a result of an astute understanding of latent needs of customers. it is difficult to envision a situation in which any of these services could have been developed on the basis of an existing set of expresses customer needs. Thus, proactive market orientation is an important platform for the implementation of internet based strategic plan. The proactive market culture enables the firm to probe into the subconscious mind of the customer to determine what they will need in time period to come (Sevester and Krones, 2012). Thus, focuses on understanding, anticipating and satisfying customers latent needs. Latent customer needs are outside the consciousness of customer (Jaworski et al, 2000 cited in Kebasta, 2010). E-commerce firms often meet latent needs by offering technological advances that enable them to lead the customer to new and better value proposition and satisfaction, rather than by responding to customer needs in the expected, previously defined product and service in the e-commerce arena are technological innovations, it is not likely that customers could articulate most needs and preference for the product. It is incumbent on the e-commerce firms to anticipate new opportunities and to deliver new benefits that may as of yet the unarticulated and unexpressed in the e-commerce market place. In other words, beyond satisfying the expresses needs of their target customers, firms define and shape the markets through proactive market culture and market-driving activities. In this context, we propose the following:

H3: The higher the proactive market culture, the greater is the influence of e-commerce competence on performance outcome.

\subsection{Environmental Factors}

Several studies have reported that the environment moderate the influence of e-commerce capability on firm performance, we conceptualized environmental factors as power supply, security and operational privacy.

We construe e-commerce security as the consumers' concern for risk of e-commerce transaction over the internet (Bom and Sirikas, 2006). In our study, we categorize electronic commerce security into four parts: data base administration, access control, computer physical security and policies. In the context of electronic payment system, security refers to the capacity of a system to reduce fraud and protect the users from the theft of their funds and personal information. Security has been a longstanding issue of e-commerce. In addition to strength of e-commerce security, secure socker layer (SSL) or transport layer security (TLS) was put in place to utilize standard certificates for authentification and data encryption to ensure privacy or confidentiality. The SSI makes it possible to encrypt credit card numbers and other transmissions between a web server and web browser (Turban et al, 2006). Today, in the world of internet computing, a firewall is a network node consisting of a public network. Some firewall filters data and requests moving from the public internet to a private network based on the network addresses of the computer sending or receiving the request. This mechanism contains the 
address of the sender as well as the address of the receiver, it also contain other identifying information that can accept or reject incoming information. This is serious security device that protect the e-commerce transaction on the internet (Washj and Sanchez, 2010). Operational privacy can be seen as the degree to which personal information cannot be divulged to another party (Ozuru and Kalu, 2006). Lichtenstein and Williamson (2007) posited that privacy has to do with the protection of personal information so that it is not disclosed to or used by other s. customers have concerns for their personal information would be sued by a third party to market new services. Operational privacy is a very serious measure of environmental factor that influence the effect of ecommerce capability on firm performance. We therefore propose the following:

H4a: Security enhances the positive effect of e-commerce competence on organizational performance.

H4b: Operational privacy enhances the positive effects of e-commerce competence on organizational performance.

H4c: Power supply enhances the positive effect of e-commerce competence on firm performance.

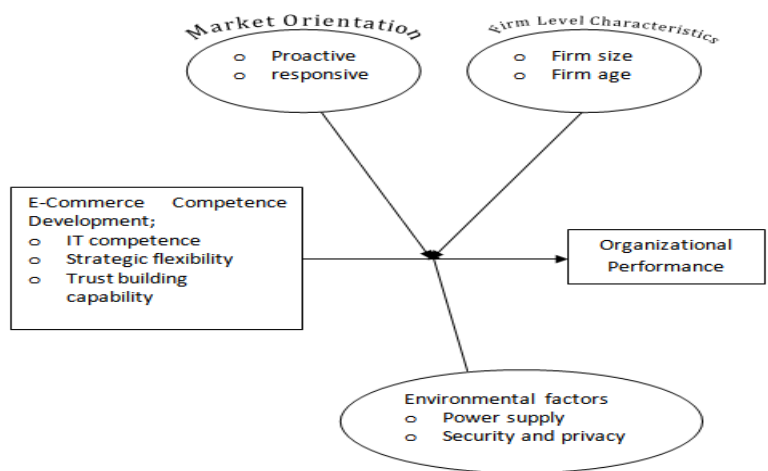

Figure1: A conceptual framework of e-commerce competence development, market orientation, firm level characteristics, environmental factors and corporate performance.

Source: Conceptualized from Review of Related Literature, 2013.

\section{Sample selection and data collection}

\section{Research Methodology}

The setting for the study is the Nigeria aviation industry which provide a universal interface for operators to participate in the aviation markets, and this suggests that the industry is a competitive context in which to examine the effect of the moderating variable on e-commerce competence. Based on the nature of the industry, we constructed our sampling frame using multiple sources, we obtained a list of our respondents from trade directory. We validate this list further using information from the Nigerian civil aviation authority (NCAA). As a result of the nature of the variables of our study our sample was made up of managers of the airlines industry in the four international airports in port Harcourt, Kanu, Lagos and Abuja. The sample size for this study was 130 respondents. The data collection yielded 122 responses of the possible 130.115 were usable for a response rate of $88 \%$. In terms of sample composition, $47 \%$ of the responses represented foreign airline firms, $38 \%$ represent domestic carriers while $15 \%$ represented regional carriers. This composition mirrors the industry split and indicates that our sample represents the true reflection of online aviation industry in Nigeria.

A close analysis of the characteristics of the sample highlighted the quality of respondents. The sampling idea was that respondents must have had the necessary capacity, not only in terms of cognition and experience, but also the residency required to ensure that content validity is attained. That given the necessary background, the same result would be achieved if the research instrument is re-administered or the study is replicated under similar circumstances. This would only result in a high degree of circumstances. This would not only result in high degree of reliability but would serve as a strong empirical frame for drawing valid practical and theoretical insights.

\section{Data Analysis}

We present the analysis in which the interaction between the moderating variables and the measures of ecommerce competence and performance is examined. In this study, four (4) hypotheses were postulated, the hypotheses presents tentative answers to our research expectations. The SPSS windows output version 17.0 was used to test the hypotheses. The test statistics used is the partial correlation coefficient, this test statistics was used because we are testing the moderating effect of the organizational factors on the independent variable and the dependent variable. 


\section{Statement of Hypothesis One}

The longer a firm level characteristics, the more skilled it is in all aspects of strategy and the more effective it is in leveraging e-commerce competencies.

Table 1: Correlation analysis showing the moderating effects of firm's level characteristics on ecommerce competence and performance.

\section{Correlations}

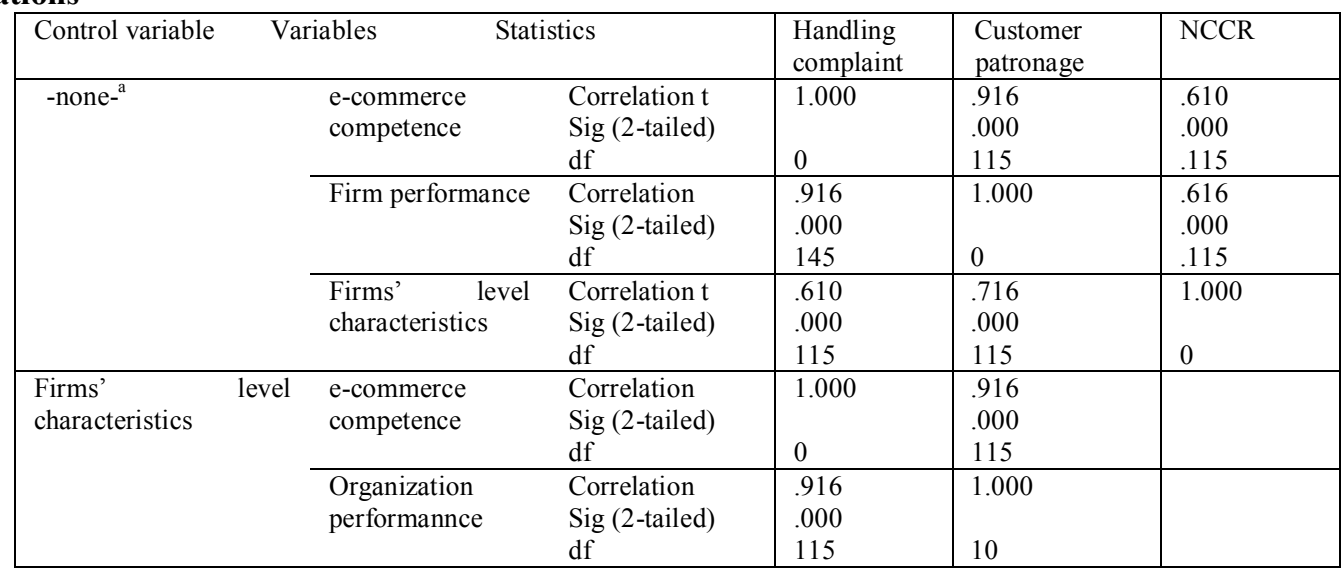

a. Cells contain zero-order (Pearson) correlation.

The result in Table 1 above reveals that there is a significant relationship existing between moderating effect of firms' level characteristics on e-commerce competence development efforts and organizational performance $(\mathrm{r}=0.916, \mathrm{Pv}=0.000<0.05)$. By this result, it means that firms' level characteristics through its moderating effect, influence e-commerce competence development on organization performance $(\mathrm{r}=0.610, \mathrm{Pv}<0.05)$ and e-commerce competence development $(\mathrm{r}=0.626, \mathrm{Pv}=0.000<0.005)$. The positive sign of this correlation coefficient shows that firms' level characteristics (size and age) moderate the effect of e-commerce competence on performance.

\section{Statement of hypothesis two}

The higher the responsive market orientation, the greater is the influence of e-commerce competence development on organizational performance.

Table 2: Correlation analysis showing the moderating effect of responsive market culture on ecommerce competence and performance outcome.

b. Correlations

\begin{tabular}{|c|c|c|c|c|c|}
\hline \multirow{2}{*}{$\begin{array}{l}\text { Control variable } \\
\text {-none- }^{\mathrm{a}}\end{array}$} & \multicolumn{2}{|l|}{ Variables } & $\begin{array}{l}\begin{array}{l}\text { Handling } \\
\text { complaint }\end{array} \\
1.000\end{array}$ & \multirow{2}{*}{$\begin{array}{l}\begin{array}{l}\text { Customer } \\
\text { patronage }\end{array} \\
178 \\
.000 \\
115\end{array}$} & \multirow{2}{*}{$\begin{array}{l}\text { NCCR } \\
.160 \\
.000 \\
.115\end{array}$} \\
\hline & $\begin{array}{l}\text { Customer care } \\
\text { management }\end{array}$ & $\begin{array}{l}\text { Correlation } t \\
\text { Sig (2-tailed) } \\
N\end{array}$ & $\begin{array}{l}1.000 \\
.081\end{array}$ & & \\
\hline & $\begin{array}{l}\text { Customer } \\
\text { Patronage }\end{array}$ & $\begin{array}{l}\text { Correlation } \\
\text { Sig (2-tailed) } \\
\mathrm{N}\end{array}$ & $\begin{array}{l}.718 \\
.081 \\
115\end{array}$ & $\begin{array}{l}1.000 \\
0\end{array}$ & $\begin{array}{l}.616 \\
.081 \\
.115\end{array}$ \\
\hline & $\begin{array}{l}\text { Information } \\
\text { competencies }\end{array}$ & $\begin{array}{l}\text { Correlation } \mathrm{t} \\
\text { Sig (2-tailed) } \\
\mathrm{N}\end{array}$ & $\begin{array}{l}.160 \\
.081 \\
115\end{array}$ & $\begin{array}{l}.166 \\
.000 \\
115\end{array}$ & $\begin{array}{l}1.000 \\
.081\end{array}$ \\
\hline \multirow[t]{2}{*}{$\begin{array}{l}\text { Information } \\
\text { competence }\end{array}$} & $\begin{array}{l}\text { Customer care } \\
\text { management }\end{array}$ & $\begin{array}{l}\text { Correlation } \\
\text { Sig (2-tailed) } \\
\mathrm{N}\end{array}$ & $\begin{array}{l}1.000 \\
.081\end{array}$ & $\begin{array}{l}.178 \\
.000 \\
115\end{array}$ & \\
\hline & $\begin{array}{l}\text { Customer } \\
\text { patronage }\end{array}$ & $\begin{array}{l}\text { Correlation } \\
\text { Sig (2-tailed) } \\
\mathrm{N}\end{array}$ & $\begin{array}{l}.178 \\
.000 \\
115\end{array}$ & $\begin{array}{l}1.000 \\
.81\end{array}$ & \\
\hline
\end{tabular}

a. Cells contain zero-order (Pearson) correlation

The result in Table 1 above reveals that there is a significant relationship existing between moderating effect of responsive market orientation e-commerce competence development efforts and organizational performance $(\mathrm{r}=0.178, \mathrm{Pv}=0.081<0.05)$. By this result, it means that responsive market orientation through its moderating effect, influence e-commerce competence development on organization performance $(\mathrm{r}=0.178$, $\mathrm{Pv}<0.05)$ and e-commerce competence development $(\mathrm{r}=0.160, \mathrm{Pv}=0.081<0.005)$. The positive sign of this correlation coefficient shows that responsive market orientation has marginal moderating effect of e-commerce competence on performance. 


\section{Statement of Hypothesis 3}

The higher the proactive market culture, the greater is the influence of e-commerce competence on performance outcome.

Table 3: correlation analysis showing the moderating effect of proactive market orientation on e-commerce competence and performance outcome.

\begin{tabular}{|c|c|c|c|c|c|c|}
\hline Control variable & \multicolumn{3}{|c|}{ Variables } & $\begin{array}{l}\text { Handling } \\
\text { complaint }\end{array}$ & $\begin{array}{l}\text { Customer } \\
\text { patronage }\end{array}$ & NCCR \\
\hline \multirow{3}{*}{\multicolumn{2}{|c|}{-none- ${ }^{\mathrm{a}}$}} & $\begin{array}{l}\text { e-commerce } \\
\text { competence }\end{array}$ & $\begin{array}{l}\text { Correlation t } \\
\text { Sig (2-tailed) } \\
\text { df }\end{array}$ & $\begin{array}{l}1.000 \\
0\end{array}$ & $\begin{array}{l}.964 \\
.000 \\
115\end{array}$ & $\begin{array}{l}.724 \\
.000 \\
.115\end{array}$ \\
\hline & & $\begin{array}{l}\text { organizational } \\
\text { performance }\end{array}$ & $\begin{array}{l}\text { Correlation } \\
\text { Sig (2-tailed) } \\
\text { df }\end{array}$ & $\begin{array}{l}.964 \\
.000 \\
145\end{array}$ & $\begin{array}{l}1.000 \\
0\end{array}$ & $\begin{array}{l}.756 \\
.000 \\
.115\end{array}$ \\
\hline & & $\begin{array}{l}\text { Proactive market } \\
\text { orientation }\end{array}$ & $\begin{array}{l}\text { Correlation t } \\
\text { Sig (2-tailed) } \\
\text { df }\end{array}$ & $\begin{array}{l}.724 \\
.000 \\
115 \\
\end{array}$ & $\begin{array}{l}.756 \\
.000 \\
115 \\
\end{array}$ & $\begin{array}{l}1.000 \\
.000 \\
\end{array}$ \\
\hline \multirow{2}{*}{\multicolumn{2}{|c|}{$\begin{array}{l}\text { Firms' } \\
\text { characteristics }\end{array}$}} & $\begin{array}{l}\text { e-commerce } \\
\text { competence }\end{array}$ & $\begin{array}{l}\text { Correlation } \\
\text { Sig (2-tailed) } \\
\text { df }\end{array}$ & $\begin{array}{l}1.000 \\
0\end{array}$ & $\begin{array}{l}.964 \\
.000 \\
115\end{array}$ & \\
\hline & & $\begin{array}{l}\text { Organization } \\
\text { performance }\end{array}$ & $\begin{array}{l}\text { Correlation } \\
\text { Sig (2-tailed) } \\
\text { df }\end{array}$ & $\begin{array}{l}.964 \\
.000 \\
115\end{array}$ & $\begin{array}{l}1.000 \\
.000\end{array}$ & \\
\hline
\end{tabular}

a. Cells contain zero-order (Pearson) correlation.

The result in table 1 above reveals that there is a significant relationship existing between moderating effect of proactive market orientation on e-commerce competence development efforts and organizational performance $(\mathrm{r}=0.724, \mathrm{Pv}=0.000<0.05)$. By this result, it means that proactive market orientation through its moderating effect, influence e-commerce competence development on organization performance $(\mathrm{r}=0.756, \mathrm{Pv}$ $<0.05)$ and e-commerce competence development efforts $(\mathrm{r}=0.160, \mathrm{Pv}=0.000<0.005)$. The positive sign of this correlation coefficient shows that proactive market orientation moderate effect of e-commerce competence on performance.

\section{Statement of Hypothesis 4}

Environmental factors (security, privacy, power) enhances the positive effects of e-commerce competence on organizational performance. The hypothesis sought to examine the relationship between environmental factors and its influence on e-commerce competence and performance outcome. The result shows a negative relationship. This is to say that, the influence of the environmental factors (security, operational privacy and power supply) on e-commerce competence has no effect on performance outcome.

We therefore reject the null hypothesis which says environmental factors therefore enhance the positive effects of e-commerce practices. Our findings indicates no effect of environmental factors on e-commerce competence development and firm performance.

\section{Discussion}

In this paper, we attempted to offer understanding of the organizational factors that moderate the effect of e-commerce competence development efforts on organizational performance. We used firms' level characteristics, market orientation and environmental forces as moderating the influence of e-commerce competence on firms' performance. Our results show notable findings.

Overall, our results offer considerable support for $\mathrm{H} 1$, which predicted a positive moderating effect between firm's level characteristics and the influence of e-commerce competence development on organizational performance. The result reported in table 1 suggest that age of the firm and size of firm which are firms' level characteristics affects the influence of e-commerce competence development on performance, this is consistent with Hensman and Volberda's (2001), Position that certain firm-level characteristics, such as firm age, signal trustworthiness. Park and Campbel (2003) argued that, the buttressing role of age is particularly important mostly in the aviation industry. Signaling reputation, age implies that the firm possesses greater knowledge stocks gained from learning and experience with the job. We found support that, the longer a firm has been in business, the more skilled it is in all aspects of strategy and the more effective it is in leveraging trust-building competencies. The experience overtime should provide a firm with knowledge bases that can couple with trust-building skills to generate positive performance outcome.

Our result do not find statistical support for the interaction between responsive market orientation and ecommerce competence on performance, the result indicate marginal evidence. The result is opposite to that hypothesized, suggesting that customer orientated culture decreases e-commerce capability development. 
Our result is not in tandem with Day's (1999) position that when customers' expressed wants and needs are understood the firm simply responds appropriately to gain competitive advantage. Christensen and Bower (1996) cited in Macuson and Binta (2010) said over dependence on customer feedback will limit strategies implementation which will affect competitive development.

The results offer equivocal support for $\mathrm{H} 3$, which predict a positive association between proactive market orientation, e-commerce competence and firm performance. Table 3 indicates that, proactive market culture is an important platform for implementing internet based strategic plans. E-commerce business are as a result of an astute understanding of latent needs of customers. Sevester and Krones (2012) argue that, the proactive market culture enables the firm to probe into the subconscious mind of the customer to determine how firms often meet latent needs by offering technological advances that enables then to lead the customer to new and better proposition and satisfaction. We conclude from the foregoing that proactive market orientation affects ecommerce capabilities to influence organizational performance measures.

Our study also documents the influence of the interaction of environmental factors and e-commerce competence which is an organizations factor. The results are opposite to that hypothesized, suggesting that environmental factors (security, privacy and power supply) decreases e-commerce competence development. The measures of environmental factors were suppose to accelerate e-commerce practices, however the hypothesis is rejected.

\section{Implications}

Our current findings are subject to verification and refinement, they offer several insights for managers of online airlines industry. Specifically, our results suggest that aviation managers should exercise caution in applying responsive market orientation. As Macuson and Binta (2010) observes, that over dependence on customer need and want will limit strategies implementation which will affect e-commerce competence development. Thus, aviation managers should be cautioned that giving customers what they ask for might not be the only or even the best approach to developing e-commerce capabilities.

Instead of a responsive market orientation, e-commerce managers might do better to adopt a proactive market orientation, they should focus on understanding, anticipating and satisfying customer's latent needs rather than speculating about customer preferences. This observation is consistent with Jaworski et al (2000), cited in Kebasta's (2010) recommendation that e-commerce firms should anticipate latent needs by offering technological advances that enable them to lead the customer to new and better value proposition and satisfaction, rather than responding to customer needs. However, our results suggest that though proactive orientation leads to development of e-commerce competencies, it also seem to result to higher cost which may affect performance.

Finally, the positive coefficients for firms' level characteristics in the analysis underscore the importance of firm size and firm age, of notes, firms in manufacturing, construction and distribution sectors, performance decreases with size of the firm. This is in consistent with Jovanovich's theory, firms uncover their true efficiencies over time (age).

Managers of e-commerce business should note the importance of number of years in business because this enables the firm to signal trustworthiness. The number of years the firm has been in business signify firms credibility. Unethical firms are not likely to survive for longer period. Age of the firm serve to buttress and validate trust building capability. Our results indicate that the influence of e-commerce competence vary according to firm level characteristics (age, size, experience). Therefore, firms' level characteristics in ecommerce business enhance performance managers should note.

Considering the uncertain climate surrounding the aviation industry in Nigeria, managers of the airlines must become increasingly savvy about the moderating effect of market orientation, firms' level characteristics and environmental factors on organization performance and the relative effectiveness of e-commerce competencies which combine with other resources to create competitive advantage in the firm. It is incumbent on marketing experts to offer current and future online managers in the aviation industry a balanced perspective of the role of organizational factors on e-commerce competence development and organizational performance in the firms. Our results are of the view that our extension of marketing wisdom drawn from this study application may not be enough.

\section{Directions For Future Study}

This study has limitations that future studies can look into, our findings add to the existing conceptual and empirical evidence that firm' level characteristics, market orientation and environmental factors moderate ecommerce competence development and organization's performance relation. Additional studies that examine the role of these moderators in a variety of contexts are warranted.

To our knowledge, this is among the few studies that have examined the moderating effect of organizational factors on e-commerce competence development and performance relation in the online aviation 
industry context, therefore, additional studies that explore this relation in other e-commerce business settings are necessary to verify the results. It would be especially interesting to determine if similar results would be found for other e-commerce practices such as online stock trading (e-trade), online auctions (ebay) and interactive customer health care.

One of the more intriguing results from our study is the findings that environmental factors (power supply, security, privacy) do not moderate the influence of e-commerce competence on performance relation. Consistent with Jaworski (2000), note that no direct relationship between e-commerce capability development and the overall firm performance when the environmental factors of uncertainty was introduced. Alternatively, these results may hold only in certain context. Future studies should explore operational privacy and security of informant as an environmental factor on e-commerce competence-performance relation in other contexts. Another area of future study is the possibility that our choice of key informant may bias our results. From our study, majority of our respondents were operations managers and marketing managers and from the resourcebased view of the firm, marketing managers hold an exaggerated view of marketing role and importance in organization. Our result may be bias. Future studies should attempt to use multiple informants from different functional areas and examines the level of coverage in respondents across different areas.

\section{Reference}

[1]. Amit, S. and Jean, J., Organizational Capabilities in e-Commerce: an Empirical Investigation of e-brokage Service Providers. Journal of the Academy of Marketing Sciences 33(3), 2005 360-375.

[2]. Assenkason, S.T and Bolton, 'Value Expectations in e-Commerce' Strategic Management Journal, 22(5), 2009, 400-420.

[3]. Augusto, G.K and Coelho, A.B, The Five Dimensions of e-Capabilities and Firm Performance" A Metal Analysis Personnel Psychology, 33(6), 2007, 1-26.

[4]. Benzack, Y.D and Srivenance, G.S, Consumer Power, Strategic Investment and the Failure of Firm Leading' Strategic Management Journal 24(5), 2008, 1-20.

[5]. Bom, K.K and Sirikas, e-Commerce interactions: Developing Scenarios, Adapting Strategic, Journal of Marketing Research and Business, 20(3), 2006, 20-29

[6]. Charkson and Batubo, K.T, ‘Determinants of Long-term Orientation in Buyer-Seller Relationship’ Journal of Marketing 58(4) 2010 $1-19$.

[7]. Chritensen, d. and bower, M.N, Customer Power, Strategic Investment and the Failure of Leading Firm, Strategic Management Journal 17(8), 1996, 197-218

[8]. Day, G.S, "the capabilities of market-driven organizations, journal of marketing 58(8), 2000, 37-52.

[9]. Dickson, P.C and Better, C.K, Strategic Marketing Planning to Radically New Product, Journal of Marketing 61(4), 2008, 1-20.

[10]. Dandison, B.B and Mitches, Y.C, 'consumer decision making in online shopping environments, journal of marketing science 19(2), 2011, 4-21.

[11]. Evans, J.S, 'strategic flexibility for high technology maneuvers, a conceptual framework, journal of management studies 28(3), 1991, 69-89.

[12]. Hall, S.T, e-Ticketing and the Nigeria Aviation Industry, Journal of Naval Science and Engineering, 21(4), $2010,20-29$.

[13]. Hensman, B.A and Batus, J.C, 'Organizational Competence and Firm Performance, Journal of International Marketing Research, 24(5), 2001, 72-85.

[14]. Hongwei, C.S and Jiang, T.T, 'the effect on a market orientation on business profitability, Journal of Business and Management Studies 31(3), 2006, 62-79.

[15]. Jaworski, B.J and Sahaj, A., 'Marketing-Driven Versus Driving Market, Journal of the Academic of Marketing Science, 28(6), $2000,45-54$

[16]. Kebasta, C.C, 'strategic and the internet practices' Harvard business review 79(3), 2010, 63-78.

[17]. Macuson, Y. and Binta, S.S, 'Firm' Level Situation and e-Marketing Practice, International Journal of Business and Management, 32(3), 2010, 46-55.

[18]. Maryland, B.C and Martins, K.T, 'Customer-Led and Market-Oriented, Strategic Management Journal, 19 (10), $2009,100-125$.

[19]. Morgan, M.N and Sanchez, C.T, 'Determinants of Long-Term Orientation in Buyer-Seller, Relationship Journal of Marketing 58(2), 2008, 1-19.

[20]. Narve and Slater, F.S 'The Effect on a Market Orientation on Business Profitability, Journal of Marketing 54(10), 1990, $20-35$.

[21]. Norver, J.C and Stanley, F.S, 'The Effect on a Market Orientation on Business Profitability, Journal of Marketing 54(10), 1990, 2035 .

[22]. Ozuru, H. and Kalu S.Ee-Marketing Practice $1^{\text {st }}$ (Ed) Prentice Hall. (2006)

[23]. Park, R. and Capbell, A., 'e-Commerce in Aviation Services: An e-agenda for Corporate Parent, European Management Journal, 19(8), 2001, 417-428.

[24]. Sevester, J.G and Krones, C.J, 'Placing Trust at the Centre of Your Internet Business, Sloan Management Review, 42(3), 2012, 3948 .

[25]. Sinclear, N.I and Tamilus, U.B, 'Trust Theory of Relationship, Journal of Marketing 56(7), 2007, $20-38$.

[26]. Wasgj, A.S and Sanchez, R., Strategic Flexibility in Product Competition, Strategic Journal 16(10), 2010, 135-159. 